\title{
Predictability of at-admission Plasma Neutrophil Gelatinase- associated Lipocalin (NGAL) Level for Acute Kidney Injury in Patients admitted to Surgical Intensive Care Unit
}

\author{
Mohamed A. Alrabiey ${ }^{(1)}$, Mamdouh Abadier (2), \\ Omminea Alsaied ${ }^{(2)}$ Ibraheim Rageh ${ }^{(3)}$ \\ Departments of Anesthesia \& ICU ${ }^{(1)}$, Medical Biochemistry ${ }^{(2)}$ \& \\ Clinical Pathology ${ }^{(3)}$, Faculty of Medicine, Benha University
}

\begin{abstract}
Objectives: To determine the frequency of acute kidney injury (AKI) among patients admitted to surgical intensive care unit (ICU) for variant indications and to determine the predictability of at admission AKI biomarkers levels for the possibility of AKI development. Patients \& Methods: The study included 168 patients with mean age of $53 \pm 6.7$ years; 97 postoperative patients, 55 trauma patients and 16 patients had other causes. Patients' data were collected and disease severity was evaluated using the Acute Physiology and Chronic Health Evaluation (APACHE II) and the simplified Therapeutic Intervention Scoring System (TISS-28). Development of AKI within the first 48 hours after ICU admission was defined according to the Acute Kidney Injury Network (AKIN) criteria using serum creatinine (sCr). Blood samples were obtained for ELISA estimation of at admission sCr and serum Cystatin C (CysC) and plasma Neutrophil gelatinase-associated lipocalin (NGAL) levels. Another blood sample was obtained at 48 hours of ICU admission for colorimetric estimation of sCr and then patients' categorization. Results: Estimated sCr at 48-hr after admission defined 62 patients developed AKI (36.9\%); 39 patients AKI stage-1 (23.2\%) and 23 patients AKI stage-2 (13.7\%). At admission plasma NGAL levels were significantly higher in patients compared to controls, however, AKI-free patients showed nonsignificantly higher plasma NGAL levels compared to controls. Patients developed AKI had significantly higher plasma NGAL levels compared to AKI-free patients with significantly higher levels in patients developed AKI-2 compared to those developed AKI-1. At admission serum CysC levels were significantly higher in patients compared to controls and in patients developed AKI-2 compared to AKI-free and AKI-1 patients. Regression and Receiver operating characteristic (ROC) analysis of at admission clinical and laboratory data as predictors for development of AKI, defined at admission plasma NGAL and serum CysC, and TISS-28 injury severity score as the significant specific predictors for possibility of development of AKI.

Conclusion: Patients admitted to surgical ICU had a risk of $36.9 \%$ for AKI development and combined high TISS-28 severity score and high at admission plasma NGAL levels could early predict the possibility of AKI development with significantly high specificity.
\end{abstract}

Keywords: Neutrophil gelatinase-associated lipocalin, Cystatin C, Acute kidney injury, Surgical ICU patients 


\section{INTRODUCTION}

Neutrophil gelatinase-associated lipocalin (NGAL) is a member of the lipocalin protein family that has diverse functions but similar structure. The functions of NGAL are not clear, but it appears to be expressed in stress conditions and in tissues undergoing involution. NGAL is a $25-\mathrm{kDa}$ secretory glycoprotein that was originally identified in human neutrophils and so was originally known as an innate immunity antibacterial factor released by activated neutrophils. NGAL is one of the most upregulated genes in the kidney soon after ischemic injury and NGAL protein was markedly induced in kidney tubule cells, and easily detected in the plasma and urine in animal models of ischemic and nephrotoxic acute kidney injury (AKI). The expression of NGAL protein was also dramatically increased in kidney tubules of humans with ischemic, septic, and posttransplant AKI ${ }^{(1-6)}$.

Cystatin $\mathrm{C}(\mathrm{CysC})$ is a 122 -amino acid, $13-\mathrm{kDa}$ protein that is a member of the family of cysteine proteinase inhibitors. It is the product of a "housekeeping" gene expressed in all nucleated cells and is produced at a constant rate. Because of its small size, CysC is freely filtered by the glomerulus. It is not secreted, but is reabsorbed by tubular epithelial cells and subsequently catabolized so that it does not return to the blood flow. This latter property negates calculation of a CysC clearance using urine concentrations of CysC. The use of serum $\mathrm{CysC}$ to estimate glomerular filtration rate is based on the same logic as the use of blood urea nitrogen and creatinine, but because it does not return to the bloodstream and is not secreted by renal tubules, it has been suggested to be closer to the "ideal" endogenous marker ${ }^{(7-9)}$.

In two large cohort studies of intensive care patients that used the Risk-Injury-Failure-Loss-End Stage (RIFLE) criteria, AKI had a prevalence of approximately $36 \%$ and was significantly associated with increased mortality ${ }^{(\mathbf{1 0}, \mathbf{1 1})}$. Similar results have been observed in the hospitalized population as a whole ${ }^{\text {(12) }}$, patients undergoing cardiac surgery $^{(13)}$, and burn patients ${ }^{(14)}$. Recently, Wohlauer et al. ${ }^{(15)}$ documented that early AKI is a harbinger of adverse outcome postinjury, outperforming hepatic, cardiac, or pulmonary dysfunction as a predictor of multiple organ failure and death, and so prevention of early AKI and a better understanding of organ crosstalk may help to reduce AKIassociated morbidity, mortality, and obligatory costs of that complication. Thus, the current study (screening study) was designed as a trial for determination of the frequency of AKI among patients admitted to surgical ICU for variant indications and to determine the predictability of at admission AKI biomarkers levels for the possibility of AKI development.

\section{PATIENTS \& METHODS}

The present prospective study was conducted at Departments of Anesthesia and Clinical Pathology, Benha University Hospital in conjunction with Medical Biochemistry Department, Faculty of 
Medicine, Benha University. After approval of the study protocol by the Local Ethical Committee and obtaining nearest patients' relative consent, patients fulfilling enrolment criteria since Jan 2010 till Jan 2013 were enrolled in the study. Also, the study included 20 age- and sexmatched controls collected from those fulfilling the preliminary investigations for blood donation at Blood Bank of Benha University

All patients' data including demographic data, admission diagnosis, associated co-morbidities and severity of illness score were determined. Severity scores were calculated for the Acute Physiology and Chronic Health Evaluation (APACHE II) $^{(\mathbf{1 6})}$ and the simplified Therapeutic Intervention Scoring System (TISS-28) ${ }^{(\mathbf{1 7})}$. Higher scores indicate more severe illness and a higher number of therapeutic interventions, respectively. For the TISS-28 score, each therapeutic intervention is assigned 1 to 4 points, and the points are summed daily to obtain the overall score. For APACHII score, zero points were usually assigned for the neurologic evaluation, since the majority of patients were sedated.

Development of AKI within the first 48 hours after ICU admission was defined according to the Acute Kidney Injury Network (AKIN) criteria using serum creatinine as shown in table $1^{(\mathbf{1 8 )}}$. Patients who developed AKI of any severity within 48 hours were classified as having day-2 AKI. Patients with more severe AKI (stages 2 or 3 ) within the first 48 hours were classified as having severe AKI. Patients requiring dialysis were classified as having AKI stage 3.

Table (1): Acute Kidney Injury Network criteria using serum creatinine ${ }^{(18)}$

\begin{tabular}{|l|l|}
\hline Stage & Serum creatinine (sCr) criteria \\
\hline 1 & $\begin{array}{l}\text { Increase in } \mathrm{sCr} \text { of } \geq 0.3 \mathrm{mg} / \mathrm{dl} \text { or increased } \mathrm{sCr} \text { by } \geq 150-200 \% \text { from } \\
\text { baseline, i.e. increase by } 1.5-2 \text { folds }\end{array}$ \\
\hline 2 & Increase in $\mathrm{sCr}$ by $>200-300 \%$ from baseline, i.e. increase by $>2-3$ folds \\
\hline 3 & Increase in $\mathrm{sCr}$ of $\geq 4 \mathrm{mg} / \mathrm{dl}$ \\
\hline
\end{tabular}

\section{Laboratory investigations}

Blood samples were drawn from antecubital vein under complete aseptic condition at time of ICU admission and were divided into three parts:

1. The first part was put in clean dry tube, allowed to clot, then serum was separated in clean dry Eppendorff tube to be stored at $80^{\circ} \mathrm{C}$ till assayed for serum Cystatin $\mathrm{C}$ level using an ELISA kit (RayBio ${ }^{\circledR}$ Human Cystatin $\mathrm{C}$
ELISA Kit, RayBio ${ }^{\circledR} \quad$ Inc., USA $)^{(19)}$.

2. The second part was collected in EDTA containing tubes. Plasma was separated as soon as possible by centrifugation at $1,500 \mathrm{~g}$ for 15 minutes and transferred to acid-handled plastic tubes, which were stored at $-80^{\circ} \mathrm{C}$ till assayed for plasma neutrophil gelatinaseassociated lipocalin using an ELISA kit (Hycult ${ }^{\circledR}$ biotech ELISA Kit, Hycult Inc.) ${ }^{(\mathbf{2 0}, \mathbf{2 1})}$. 
3. The third part was put in clean dry tube and allowed to clot and then serum was separated for estimation of serum creatinine using commercial colorimetric kit (Neogen Corporation, Lexington, USA) ${ }^{(22)}$. Another blood sample was obtained at 48 hours of ICU admission for ELISA estimation of serum creatinine.

Patients' categorization:

The percentage of $\mathrm{sCr}$ change was calculated as level of $\mathrm{sCr}$ estimated at 48-hr minus that estimated at admission and the resultant was divided by the level estimated at admission and patients were categorized according to the percentage of change into AKI stage13.

\section{RESULTS}

The study included 168 patients admitted to ICU; 115 males $(68.5 \%)$ and 53 females $(31.5 \%)$; with mean age of 53 \pm 6.7 ; range: $35-63$ years. The mean BMI was $34.6 \pm 2.7$; range: $30.5-39.5 \mathrm{~kg} / \mathrm{m}^{2}$. There was nonsignificant $\quad(\mathrm{p}>0.05) \quad$ difference between patients and controls as regards enrollment demographic data, (Table 2). Concerning the cause of admission; 97 patients $(57.7 \%)$ were postoperative patients, 55 patients $(32.7 \%)$ were patients who suffered trauma and 16 patients $(9.6 \%)$ had other causes. Fifty-two patients $(30.9 \%)$ had no associated comorbidities, while 116 patients (69.1\%) had additional comorbidities. Mean APACHE II score determined at first $24 \mathrm{hrs}$ after ICU admission was $15.6 \pm 4.6$; range: 7-23. Median APACHE II score was 15 and
88 patients $(52.4 \%)$ had score $\geq 15$. Mean TISS-28 score at first 24 hours after ICU admission was 40.2 \pm 4.5 ; range: $32-49$. Median TISS-28 score was 41 and 78 patients $(46.4 \%)$ had score $\geq 41$, (Table 3 ).

Estimated serum creatinine at 48 hr after admission defined 62 patients developed AKI for a frequency of AKI among ICU patients of $36.9 \%$; with mean percentage of increased sCr of 206 \pm 44 ; range: $152.5-323.5 \%$. Fortunately, no case showed shooting $\mathrm{sCr}$ at 48 hours estimation time, so no case of AKI stage-3 was reported. Thirty-nine patients developed AKI stage-1 for a frequency of stage- 1 of $23.2 \%$ with mean percentage of increased $\mathrm{sCr}$ of $187.6 \pm 18.8$; range: $152.5-226 \%$. Twenty-three patients developed AKI stage-2 for a frequency of stage- 2 of $13.7 \%$ with mean percentage of increased $\mathrm{sCr}$ of 238 \pm 55 ; range: $182-323.5 \%$ (Table 4, Fig. 1).

Patients who were free of AKI at 48-hr after ICU admission had nonsignificantly $\quad(p>0.05)$ higher at admission $\mathrm{sCr}$ compared to control subjects. On contrary, patients developed AKI had significantly $(\mathrm{p}<0.05)$ higher at admission $\mathrm{sCr}$ compared to controls and to AKI-free patients. Patients developed AKI stage-1 had significantly $(\mathrm{p}<0.05)$ higher at admission $\mathrm{sCr}$ levels compared to controls, but had nonsignificantly $(p>0.05)$ higher levels compared to AKI-free patients. Patients developed AKI stage-2 had significantly $(p<0.05)$ higher at admission $\mathrm{sCr}$ levels compared to controls, AKI-free patients and to patients had AKI stage-1. Mean patients' $\mathrm{sCr}$ estimated at 48-hr after 
ICU admission was significantly $(\mathrm{p}<0.05)$ higher compared to their respective at admission $\mathrm{sCr}$ level. Moreover, mean sCr estimated at 48$\mathrm{hr}$ after ICU was significantly $(\mathrm{p}<0.05)$ higher in patients compared to controls with significantly $(\mathrm{p}<0.05)$ higher $\mathrm{sCr}$ estimated at $48-\mathrm{hr}$ in patients developed AKI compared to controls and to AKI-free patients. Patients had AKI stage-2 showed significantly $(\mathrm{p}<0.05)$ higher $\mathrm{sCr}$ estimated at 48-hr compared to controls, AKI-free patients and patients had AKI stage-1. Patients had AKI stage-1 showed significantly $(\mathrm{p}<0.05)$ higher $\mathrm{sCr}$ estimated at 48-hr compared to controls and AKI-free patients. Patients free of AKI showed significantly $(\mathrm{p}<0.05)$ higher $\mathrm{sCr}$ estimated at $48-\mathrm{hr}$ compared to controls, (Table 4, Fig. 2).

At admission plasma NGAL levels were significantly $(p<0.05)$ higher in patients compared to controls, however, AKI-free patients showed non-significantly $(\mathrm{p}>0.05)$ higher plasma NGAL levels compared to controls. Patients developed AKI had significantly $(\mathrm{p}<0.05)$ higher plasma NGAL levels compared to AKI-free patients with significantly $(p<0.05)$ higher levels in patients developed AKI-2 compared to those developed AKI-1, (Table 5, Fig. 3). Similarly, at admission serum CysC levels were significantly $(p<0.05)$ higher in patients compared to controls and in patients developed AKI-2 compared both to AKI-free patients and those developed AKI-1 with non-significantly ( $p>0.05)$ higher levels detected in patients had AKI-1 compared to AKI-free patients, (Table 5, Fig. 4).

Regression analysis of at admission clinical and laboratory data as predictors for development of AKI, defined plasma NGAL as the significant predictor for possibility of development of AKI in four models, followed by at admission serum cystatin $\mathrm{C}$ in three models, TISS-28 injury severity score in two models and at admission serum creatinine in one model, (Table 6). ROC curve analysis for specificity of these predictors, defined at admission plasma NGAL as the significant specific predictor for possibility of development of AKI, followed by serum cystatin $\mathrm{C}$ and lastly at admission TISS-28 score and presence of additional co-morbidities, (Table 7 , Fig. 5).

Table (2): Enrollment demographic data of studied patients compared to controls

\begin{tabular}{|l|l|l|l|}
\hline \multicolumn{2}{|c|}{} & Controls & Patients \\
\hline \multicolumn{2}{|l|}{ Age (years) } & $56.1 \pm 8.2(37-65)$ & $53 \pm 6.7(35-63)$ \\
\hline \multirow{2}{*}{ Gender } & Males & $14(70 \%)$ & $115(68.5 \%)$ \\
\cline { 2 - 4 } & Females & $6(30 \%)$ & $53(31.5 \%)$ \\
\hline \multirow{2}{*}{$\begin{array}{l}\text { Anthropometric } \\
\text { data }\end{array}$} & Weight $(\mathrm{kg})$ & $94 \pm 4(85-102)$ & $94.5 \pm 6.3(82-108)$ \\
\cline { 2 - 4 } & Height $(\mathrm{cm})$ & $164.6 \pm 3.3(160-170)$ & $165.3 \pm 3.7(159-172)$ \\
\cline { 2 - 4 } & BMI $\left(\mathrm{kg} / \mathrm{m}^{2}\right)$ & $34.7 \pm 2.3(31.6-37.9)$ & $34.6 \pm 2.7(30.5-39.5)$ \\
\hline
\end{tabular}

Data are presented as mean \pm SD \& numbers; ranges \& percentages are in parenthesis 
Table (3): Clinical data and initial scoring at time of admission to ICU

\begin{tabular}{|c|c|c|c|}
\hline \multicolumn{3}{|l|}{ Data } & Findings \\
\hline \multirow{5}{*}{\multicolumn{2}{|c|}{$\begin{array}{l}\text { Associated medical } \\
\text { disorders }\end{array}$}} & No & $52(30.9 \%)$ \\
\hline & & Diabetes mellitus & $23(13.7 \%)$ \\
\hline & & Previous cardiac disease & $49(29.2 \%)$ \\
\hline & & Hypertension & $31(18.5 \%)$ \\
\hline & & Chronic kidney disease & $13(7.7 \%)$ \\
\hline \multirow{8}{*}{$\begin{array}{l}\text { Causes of } \\
\text { admission }\end{array}$} & \multirow[t]{4}{*}{ Postoperative } & Major Abdominal surgery & $31(18.5 \%)$ \\
\hline & & Thoracic surgery & $22(13.1 \%)$ \\
\hline & & Neurosurgery & $25(14.9 \%)$ \\
\hline & & Major orthopedic surgery & $19(11.3 \%)$ \\
\hline & \multicolumn{2}{|c|}{ Multiple trauma } & $55(32.6 \%)$ \\
\hline & \multirow[t]{3}{*}{ Others } & Acute coronary disease & $9(5.4 \%)$ \\
\hline & & Hyperosmolar hyperglycemic coma & $4(2.4 \%)$ \\
\hline & & Respiratory failure & $3(1.8 \%)$ \\
\hline \multirow{4}{*}{\multicolumn{2}{|c|}{$\begin{array}{l}\text { APACHE II score at } 1^{\text {st }} 24- \\
\text { hrs }\end{array}$}} & Mean & $15.6 \pm 4.6$ \\
\hline & & Range & $7-23$ \\
\hline & & Median & 15 \\
\hline & & $\begin{array}{l}\text { Number }(\%) \text { with score } \geq \text { median } \\
\text { score }\end{array}$ & $88(52.4 \%)$ \\
\hline \multirow{4}{*}{\multicolumn{2}{|c|}{ TISS-28 score at $1^{\text {st }} 24-\mathrm{hrs}$}} & Mean & $40.2 \pm 4.5$ \\
\hline & & Range & $32-49$ \\
\hline & & Median & 41 \\
\hline & & $\begin{array}{l}\text { Number }(\%) \text { with score } \geq \text { median } \\
\text { score }\end{array}$ & $78(46.4 \%)$ \\
\hline
\end{tabular}

Data are presented as mean \pm SD \& numbers; ranges \& percentages are in parenthesis

Table (4): Mean serum creatinine levels estimated at admission and 48-hr after ICU admission in patients categorized according to presence and stage of AKI

\begin{tabular}{|c|c|c|c|c|c|}
\hline & At admission & $\begin{array}{l}\text { At } 48 \text {-hr after } \\
\text { admission }\end{array}$ & $\begin{array}{l}\text { Percentage of } \\
\text { change }\end{array}$ \\
\hline \multicolumn{3}{|c|}{ Control $(n=20)$} & $\begin{array}{l}0.89 \pm 0.18 \\
(0.67-1.02)\end{array}$ & - & - \\
\hline \multirow[t]{5}{*}{ Patients } & \multicolumn{2}{|c|}{ AKI-free $(n=106)$} & $\begin{array}{l}0.95 \pm 0.1 \\
(0.74-1.06)\end{array}$ & $\begin{array}{l}1.04 \pm 0.05^{\mathrm{AD}} \\
(0.87-1.11)\end{array}$ & $\begin{array}{l}7.3 \pm 4.3 \\
(1.4-23.1)\end{array}$ \\
\hline & \multirow[t]{3}{*}{ AKI } & $\begin{array}{l}\text { AKI-1 } \\
(\mathrm{n}=39)\end{array}$ & $\begin{array}{l}0.98 \pm 0.07^{\mathrm{A}} \\
(0.82-1.07)\end{array}$ & $\begin{array}{l}2.72 \pm 0.34^{\text {ABD }} \\
(1.98-3.32)\end{array}$ & $\begin{array}{l}187.6 \pm 18.8 \\
(152.5-226)\end{array}$ \\
\hline & & $\begin{array}{l}\text { AKI-2 } \\
(n=23)\end{array}$ & $\begin{array}{l}1.42 \pm 0.34^{\mathrm{ABC}} \\
(1.04-2.03)\end{array}$ & $\begin{array}{l}4.64 \pm 0.52^{\text {АBCD }} \\
(4-5.8)\end{array}$ & $\begin{array}{l}238 \pm 55 \\
(182-323.5)\end{array}$ \\
\hline & & $\begin{array}{l}\text { Total } \\
(n=62)\end{array}$ & $\begin{array}{l}1.15 \pm 0.32^{\mathrm{AB}} \\
(0.74-2.03)\end{array}$ & $\begin{array}{l}3.43 \pm 1.02^{\mathrm{AD}} \\
(1.98-5.8)\end{array}$ & $\begin{array}{l}206 \pm 44 \\
(152.5-323.5)\end{array}$ \\
\hline & \multicolumn{2}{|c|}{ Total $(n=168)$} & $\begin{array}{l}1.18 \pm 0.34^{\mathrm{A}} \\
(0.89-2.11)\end{array}$ & $\begin{array}{l}1.93 \pm 1.31^{\mathrm{ABD}} \\
(0.87-5.8)\end{array}$ & $\begin{array}{l}56.9 \pm 84.4 \\
(1.5-323.5)\end{array}$ \\
\hline
\end{tabular}

Data are presented as mean $\pm \mathrm{SD}$, ranges are in parenthesis; ${ }^{\mathbf{A}}$ : significant versus controls; $^{\mathbf{B}}$ : significant versus no $\mathrm{AKI}{ }^{{ }^{\mathbf{C}} \text { : }}$ significant versus AKI-1; ${ }^{\mathbf{D}}$ : significant versus at admission 
Table (5): Mean at admission plasma NGAL and serum cystatin C levels estimated in patients categorized according to presence and stage of AKI

\begin{tabular}{|c|c|c|c|c|}
\hline & & & NGAL (ng/ml) & Cystatin C (ng/ml) \\
\hline Control & $=20)$ & & $55 \pm 10.9(33-78)$ & $251.2 \pm 55.4(167-339)$ \\
\hline Patients & AKI- & $(n=106)$ & $58 \pm 11.8$ & $327.9 \pm 59.1^{\mathbf{A}}$ \\
\hline & AKI & $\begin{array}{l}\text { AKI-1 } \\
(n=39)\end{array}$ & $\begin{array}{l}177.5 \pm 36.3^{\mathbf{A B}} \\
(105-245)\end{array}$ & $\begin{array}{l}351.6 \pm 74.2^{\mathbf{A}} \\
(245-435)\end{array}$ \\
\hline & & $\begin{array}{l}\text { AKI-2 } \\
(n=23)\end{array}$ & $\begin{array}{l}288.8 \pm 85.6^{\mathbf{A B C}} \\
(178-422)\end{array}$ & $\begin{array}{l}453.6 \pm 91.8^{\mathbf{A B C}} \\
(309-650)\end{array}$ \\
\hline & & $\begin{array}{l}\text { Total } \\
(\mathrm{n}=62)\end{array}$ & $\begin{array}{l}218.8 \pm 80^{\mathbf{A B}} \\
(105-422)\end{array}$ & $\begin{array}{l}370.1 \pm 100.8^{\mathbf{A B}} \\
(245-650)\end{array}$ \\
\hline & Total & $=168)$ & $\begin{array}{l}117.3 \pm 92.1^{\mathbf{A}} \\
(32-422)\end{array}$ & $\begin{array}{l}350.6 \pm 74.9^{\mathbf{A}} \\
(198-650)\end{array}$ \\
\hline
\end{tabular}

Data are presented as mean $\pm \mathrm{SD}$, ranges are in parenthesis; ${ }^{\mathbf{A}}$ : significant versus controls; ${ }^{\mathbf{B}}$ : significant versus AKI-free; ${ }^{\mathbf{C}}$ : significant versus AKI-1

Table (6): Regression analysis of laboratory parameters estimated at time of ICU admission and clinical data as predictors for the possibility of development of AKI

\begin{tabular}{|l|l|l|l|l|}
\hline & & $\boldsymbol{\beta}$ & $\mathbf{T}$ & $\mathbf{p}$ \\
\hline \multirow{4}{*}{ Model 1 } & Serum creatinine & 0.148 & 2.000 & $=0.047$ \\
\cline { 2 - 5 } & TISS-28 score & 0.186 & 2.863 & $=0.005$ \\
\cline { 2 - 5 } & Serum CysC & 0.229 & 3.537 & 0.001 \\
\cline { 2 - 5 } & Plasma NGAL & 0.511 & 6.916 & $<0.001$ \\
\hline Model 2 & TISS-28 score & 0.174 & 2.670 & $=0.008$ \\
\cline { 2 - 5 } & Serum CysC & 0.224 & 3.422 & $=0.001$ \\
\cline { 2 - 5 } & Plasma NGAL & 0.439 & 6.740 & $<0.001$ \\
\hline Model 3 & Serum CysC & 0.241 & 3.643 & $<0.001$ \\
\cline { 2 - 5 } & Plasma NGAL & 0.451 & 6.801 & $<0.001$ \\
\hline Model 4 & Plasma NGAL & 0.475 & 6.960 & $<0.001$ \\
\hline
\end{tabular}

$\beta$ : Standardized coefficient; TISS-28: simplified Therapeutic Intervention Scoring System; CysC: Cystatin C; NGAL: Neutrophil gelatinase-associated lipocalin. 
Table (7): ROC curve analysis of laboratory parameters estimated at time of ICU admission and clinical data as predictors for the possibility of development of AKI

\begin{tabular}{|l|l|l|l|l|l|}
\hline & AUC & S.E & P & CI & \\
\cline { 5 - 6 } & & & & Upper & Lower \\
\hline Age & 0.587 & 0.046 & $>0.05$ & 0.496 & 0.678 \\
\hline Additional co-morbidities & 0.628 & 0.045 & $=0.006$ & 0.538 & 0.715 \\
\hline APACHE II score & 0.577 & 0.045 & $>0.05$ & 0.489 & 0.665 \\
\hline TISS-28 score & 0.628 & 0.045 & $=0.006$ & 0.539 & 0.717 \\
\hline Plasma NGAL & 0.799 & 0.035 & $<0.001$ & 0.731 & 0.867 \\
\hline Serum CysC & 0.646 & 0.046 & $=0.002$ & 0.555 & 0.736 \\
\hline Serum creatinine & 0.608 & 0.046 & $=0.020$ & 0.518 & 0.698 \\
\hline
\end{tabular}

AUC: Area under curve; S.E: Standard error; CI: confidence interval; TISS-28: simplified Therapeutic Intervention Scoring System; CysC: Cystatin C; NGAL: Neutrophil gelatinase-associated lipocalin.

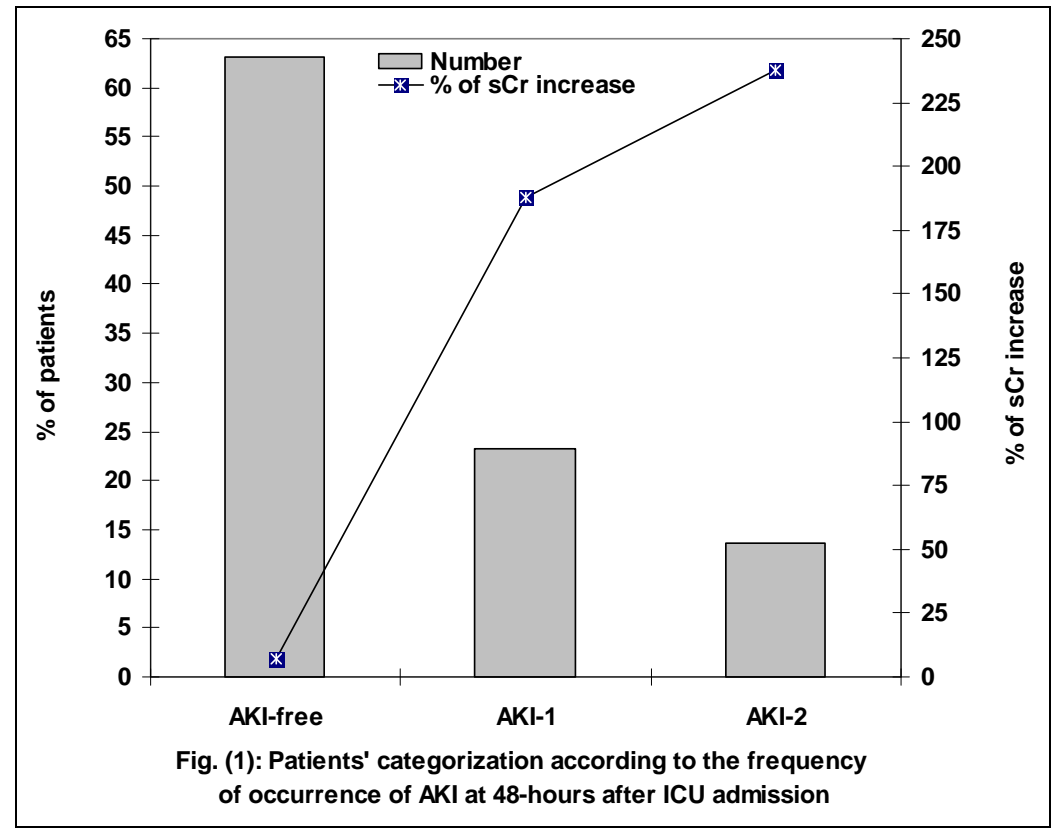




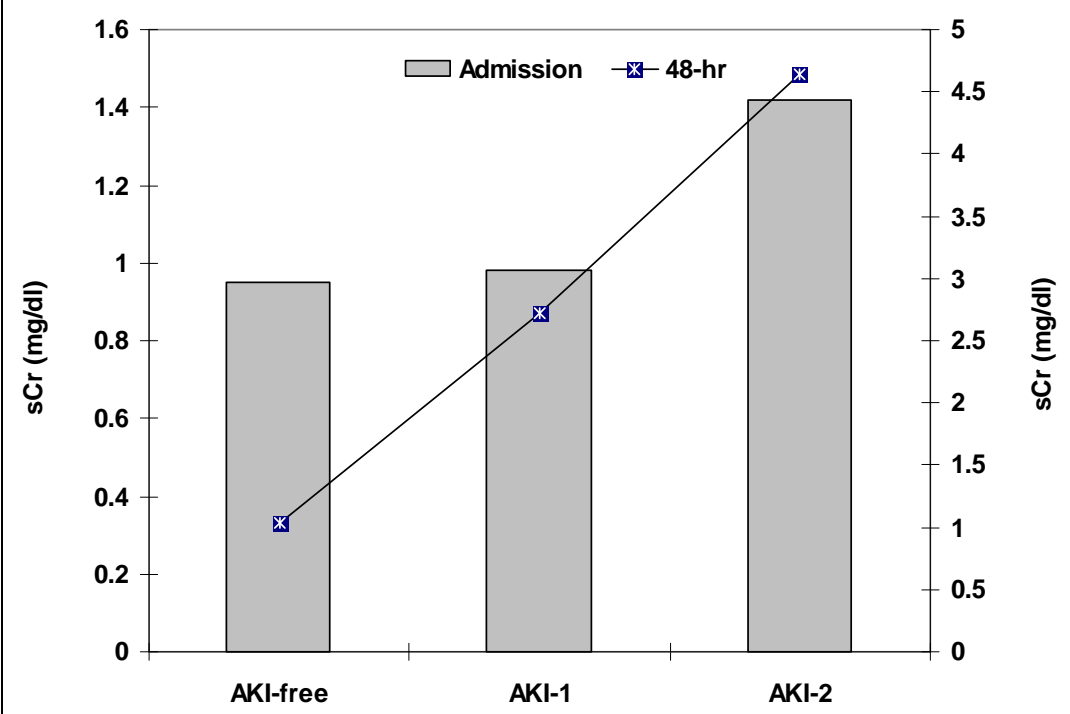

Fig. (2): Mean serum creatinine levels estimated at time of admission and 48-hr thereafter in studied patients' categorization according to the frequency of occurrence of $\mathrm{AKI}$ at 48-hours after

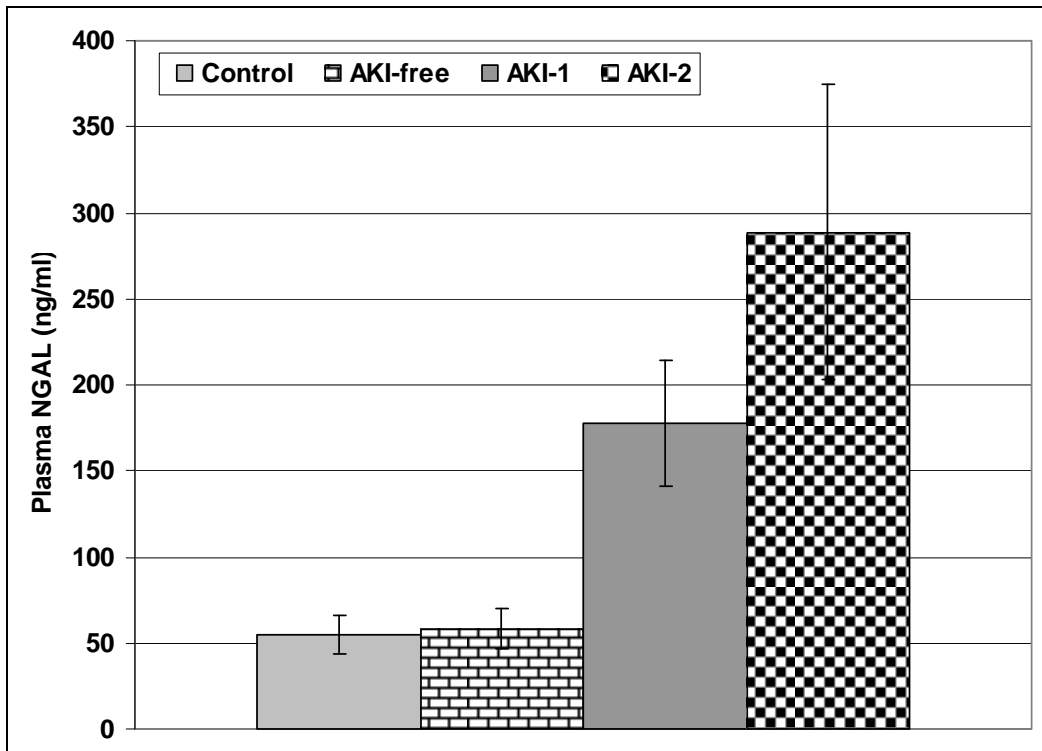

Fig. (3): Mean ( $(+S D)$ at admission plasma NAGL levels estimated in studied patients categorized according occurrence and severity of AKI 


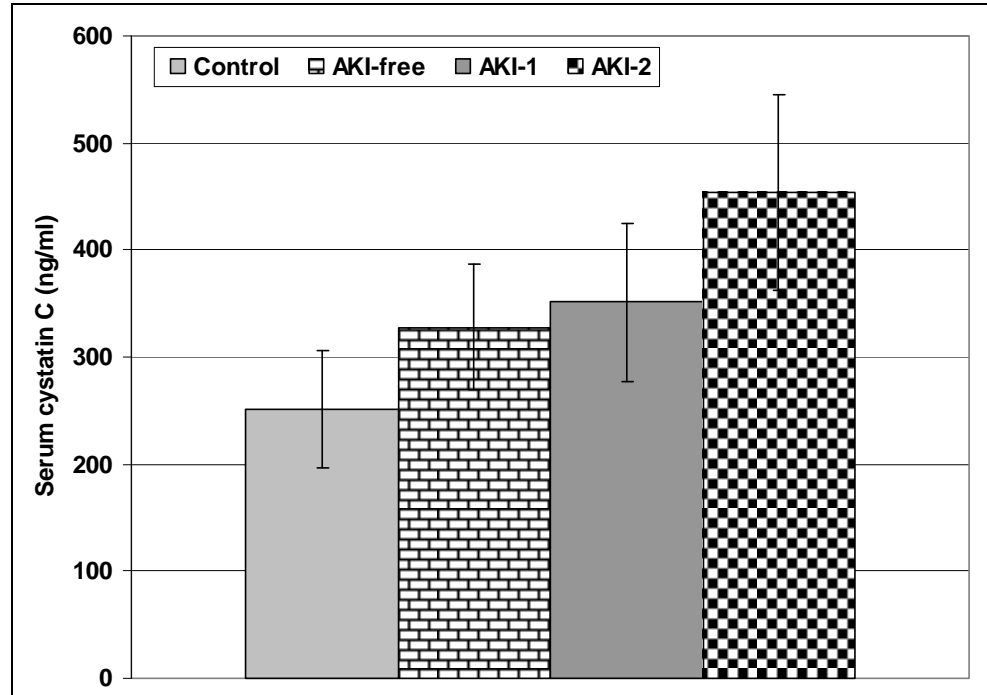

Fig. (4): Mean (+SD) at admission serum cystatin C levels estimated in studied patients categorized according occurrence and severity of AKI

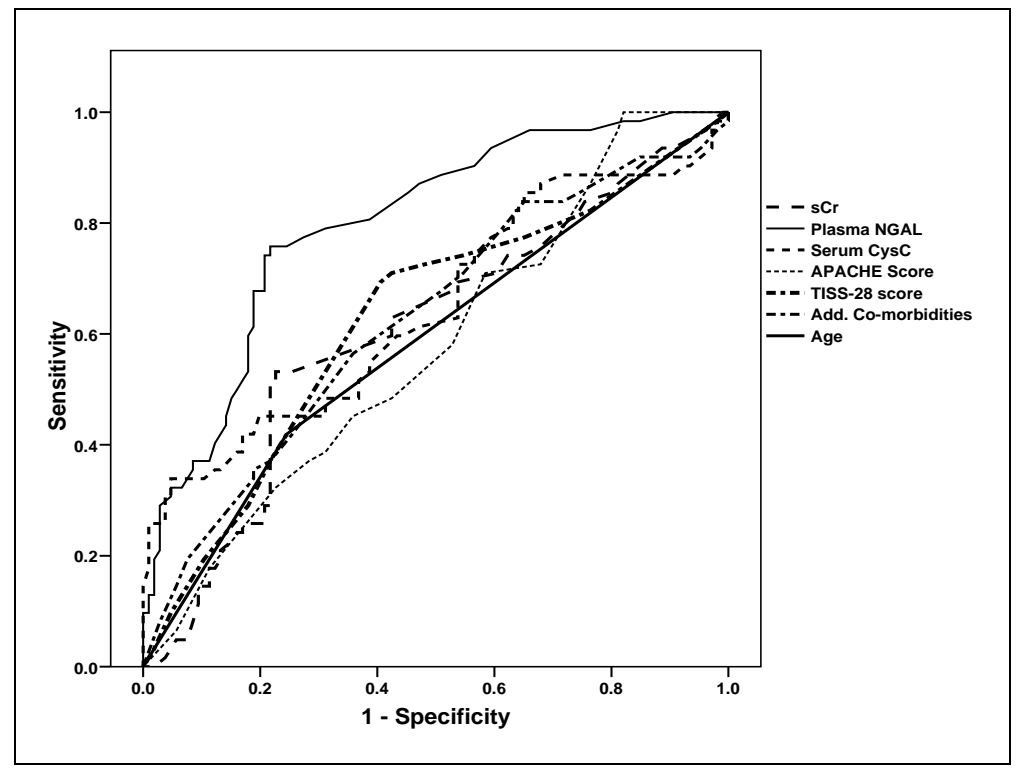

Fig. (5): ROC curve analysis of laboratory parameters estimated at time of ICU admission and clinical data as predictors for the possibility of development of AKI 


\section{DISCUSSION}

Among 168 patients admitted to surgical ICU, 62 patients developed AKI as documented by increased serum creatinine $(\mathrm{sCr})$ level estimated at 48-hr after ICU admission in relation to at admission $\mathrm{sCr}$ level, for a frequency of AKI development of $36.9 \%$; according to AKIN criteria, 39 patients had AKI stage-1 (23.2\%) and 23 patients had AKI stage-2 (13.7\%) and fortunately no patient had AKI stage-3. In line with these figures; Cruz et al. ${ }^{(23)}$ reported a frequency of AKI of $44 \%$ of 301 patients during their ICU stay. Kashani et al. ${ }^{(24)}$ studied 522 adults in three distinct cohorts including patients with sepsis, shock, major surgery, and trauma and reported moderate to severe AKI in $14 \%$ of studied patients. Talving et al. ${ }^{(25)}$ reported a frequency of $13.4 \%$ among 521 studied pediatrics admitted to trauma surgical ICU.

Despite the significantly higher at admission $\mathrm{sCr}$ in patients developed AKI in comparison to controls and AKI-free patients, patients developed AKI stage- $1 \quad(n=39 ; 62.9 \%)$ had their at admission $\mathrm{sCr}$ was in range of $0.82-$ $1.07 \mathrm{mg} / \mathrm{dl}$ which falls in the normal range of $\mathrm{sCr}$. These findings indicated the shortage of at admission estimation of $\mathrm{sCr}$ as a predictor for the possibility of development of AKI. In support of that assumption, regression analysis failed to define at admission $\mathrm{sCr}$ as significant specific predictor except in one of four models of analysis. In hand with these data, de Geus et al. ${ }^{\text {(26) }}$ documented that efforts to change the clinical course of AKI have failed because clinically available therapeutic measures are currently lacking, and early detection is impossible with serum creatinine.

At admission high serum cystatin $\mathrm{C}$ (CysC) levels were found as a significant specific predictor for AKI in three models of regression analysis with high AUC; however its predictivity was inferior to that of NGAL and when coupled its predictivity became better. In support of these findings, Cai et al. ${ }^{(27)}$ reported that $\mathrm{CysC}$ is a more accurate and sensitive marker for identification of acute impaired renal function in major burn patients than $\mathrm{sCr}$, so it is important to measure $\mathrm{CysC}$ and calculate estimated glomerular filtration rate to prevent acute renal failure and modify drug doses in burn patients, especially those of older age and with major burn areas. Aydoğdu et al. ${ }^{(28)}$ found plasma and urinary CysC and urinary NGAL are useful markers in predicting AKI in septic ICU patients.

At admission plasma NGAL levels were found to be the best early predictor for the possibility of AKI development in patients admitted to surgical ICU. This outcome was confirmed statistically, where both $\mathrm{ROC}$ and regression analyses defined it as the significant specific predictor for the possibility of development of AKI. In line of these data, Mårtensson et al. ${ }^{(29)}$ found plasma NGAL is raised in patients with systemic immune response, severe sepsis, and septic shock. Bagshow et al. ${ }^{(30)}$ reported that septic AKI patients have higher detectable plasma NGAL compared with non-septic AKI patients and these differences in NGAL values in septic AKI have diagnostic and clinical relevance as 
well as pathogenetic implications. Constantin et al. $^{(31)}$ assessed the ability of plasma NGAL to predict AKI in adult ICU patients and found its sensitivity was $85 \%$ and specificity was $97 \%$ for predication of AKI. Koyner et al. ${ }^{(32)}$ tried to evaluate whether kidney injury biomarkers measured at the time of first clinical diagnosis of early AKI after cardiac surgery can forecast AKI severity and found that each biomarker improved risk classification compared with the clinical model alone, with plasma NGAL performing the best. Mellor \& Woods ${ }^{(33)}$ found serum NGAL levels raised in both groups of casualties, blast and gunshot wounds, and was significantly predictive of death or renal failure at ICU admission, 12 and 24 hours after injury.

Additionally, presence of additional co-morbidities and high TISS-28 scores were found to be specific predictors for AKI, however, AUC for both clinical data was less than AUC for NGAL, thus combined clinical judgment and high at admission plasma NGAL improved the predictivity for the possibility of development of AKI. In line with these data; Di Somma et al. (34) reported that the AUC, obtained at time-0 (T0), for blood NGAL alone in the AKI group was 0.80 and when NGAL at T0 was added to the physician's initial clinical judgment the AUC was increased to 0.90, significantly greater when compared to the AUC of the T0 estimated glomerular filtration rate and concluded that assessment of a patient's initial blood NGAL when admitted to hospital improved the initial clinical diagnosis of AKI and predicted in-hospital mortality.

In support of the predictivity of estimation of plasma NGAL, Kümpers et al. ${ }^{(35)}$ reported that serum NGAL can be used as an outcomespecific biomarker in critically ill patients at initiation of renal replacement therapy and results indicated that serum NGAL could be used as an independent predictor of 28-day mortality in ICU patients with dialysis-dependent AKI. Recently, Polat et al. (36) reported that in a heterogeneous group of critically ill children with established AKI, NGAL in both urine and serum at the time of patient presentation discriminated intrinsic AKI from prerenal AKI.

The obtained results and review of literature allowed concluding that patients admitted to surgical ICU had a risk of $36.9 \%$ for AKI development and combined high TISS-28 severity score and high at admission plasma NGAL levels could early predict the possibility of AKI development with significantly high specificity.

\section{REFERENCES}

1. Kjeldsen L, Johnsen AH, Sengelov $\mathrm{H}$, Borregaard $\mathbf{N}$ (1993): Isolation and primary structure of NGAL, a novel protein associated with human neutrophil gelatinase. J. Biol. Chem., 268(14): 10425-32.

2. Mishra J, Ma Q, Prada A, Mitsnefes M, Zahedi K, Yang J, Barasch J, Devarajan P (2003): Identification of neutrophil gelatinase-associated lipocalin as a novel early urinary biomarker 
for ischemic injury. J. Am. Soc. Nephrol., 14(10):2534-43.

3. Mishra J, Mori K, Ma Q, Kelly C, Barasch J, Devarajan $\mathbf{P}$ (2004): Neutrophil GelatinaseAssociated Lipocalin (NGAL): a novel early urinary biomarker for cisplatin nephrotoxicity. Am J Nephrol.; 24(3):307-15.

4. Mori K, Lee HT, Rapoport D, Drexler IR, Foster K, Yang J, Schmidt-Ott KM, Chen X, Li JY, Weiss S, Mishra J, Cheema FH, Markowitz G, Suganami T, Sawai K, Mukoyama M, Kunis C, D'Agati V, Devarajan $P$, Barasch J. (2005): Endocytic delivery of lipocalin-siderophoreiron complex rescues the kidney from ischemia- reperfusion injury. J. Clin. Invest., 115(3):610-21.

5. Mishra J, Dent C, Tarabishi R, Mitsnefes MM, Ma Q, Kelly C, Ruff SM, Zahedi K, Shao M, Bean J, Mori K, Barasch J, Devarajan P. (2005): Neutrophil gelatinase-associated lipocalin (NGAL) as a biomarker for acute renal injury after cardiac surgery. Lancet 365(9466):1231-8.

6. Bao G, Clifton M, Hoette TM, Mori K, Deng SX, Qiu A, Viltard M, Williams D, Paragas N, Leete T, Kulkarni R, Li X, Lee B, Kalandadze A, Ratner AJ, Pizarro JC, Schmidt-Ott KM, Landry DW, Raymond KN, Strong RK, Barasch J. (2010): Iron traffics in circulation bound to a siderocalin (ngal)catechol complex. Nat.Chem. Biol., 6(8): 602-9.

7. 7.Kyhse-Andersen J, Schmidt C, Nordin G, Andersson B,
Nilsson-Ehle $\mathbf{P}$, Lindström V, Grubb A (1994): Serum cystatin C, determined by a rapid, automated particle-enhanced turbidimetric method, is a better marker than serum creatinine for glomerular filtration rate. Clin. Chem., 40(10):1921-6.

8. Laterza OF, Price CP, Scott MG (2002): Cystatin C: an improved estimator of glomerular filtration rate? Clin. Chem., 48(5):699-707.

9. Salgado JV, Neves FA, Bastos MG, França AK, Brito DJ, Santos EM, Salgado Filho N (2010): Monitoring renal function: measured and estimated glomerular filtration rates - a review. Braz J. Med. Biol. Res., 43(6):528-36.

10. Ostermann $M$, Chang RW (2007): Acute kidney injury in the intensive care unit according to RIFLE. Crit. Care Med., 35(8): 1837-43.

11. Bagshaw SM, George C, Dinu I, Bellomo R (2008): A multicentre evaluation of the RIFLE criteria for early acute kidney injury in critically ill patients. Nephrol. Dial. Transplant., 23(4): 1203-10.

12. Uchino $S$, Bellomo $R$, Goldsmith D, Bates S, Ronco C (2006): An assessment of the RIFLE criteria for acute renal failure in hospitalized patients. Crit. Care Med., 34(7): 1913-7.

13. Kuitunen A, Vento A, Suojaranta-Ylinen R, Pettila V (2006): Acute renal failure after cardiac surgery: Evaluation of the RIFLE classification. Ann. Thorac. Surg., 81(2): 542-6. 
14. Steinvall I, Bak $Z$, Sjoberg $F$ (2008): Acute kidney injury is common, parallels organ dysfunction or failure, and carries appreciable mortality in patients with major burns: A prospective exploratory cohort study. Crit. Care 12(5): R124.

15. Wohlauer MV, Sauaia A, Moore EE, Burlew CC, Banerjee A, Johnson J (2012): Acute kidney injury and posttrauma multiple organ failure: the canary in the coal mine. J. Trauma Acute Care Surg., 72(2):373-78.

16. Knaus WA, Draper EA, Wagner DP, Zimmerman JE (1985): APACHE II: a severity of disease classification system. Crit. Care Med., 13(10): 818-29.

17. Miranda DR, de Rijk A, Schaufeli W (1996): Simplified Therapeutic Intervention Scoring System: the TISS-28 items results from a multicenter study. Crit. Care Med., 24(1): 64-73.

18. Mehta RL, Kellum JA, Shah SV, Molitoris BA, Ronco C, Warnock DG, Levin A (2007): Acute Kidney Injury Network: report of an initiative to improve outcomes in acute kidney injury. Crit. Care 11(2): R31.

19. Conti M, Moutereau S, Zater M, Lallali K, Durrbach A, Manivet P, Eschwege P, Loric S (2006). Urinary cystatin $C$ as a specific marker of tubular dysfunction. Clin. Chem. Lab. Med., 44 (3):288-91

20. Mishra J, Ma Q, Kelly C, Mitsnefes M, Mori K, Barasch J, Devarajan P (2006): Kidney NGAL is a novel early marker of acute injury following transplantation. Pediatr. Nephrol., 21(6): 856-63.

21. Hirsch $\mathbf{R}$, Dent $C$, Pfriem $H$, Allen J, Beekman RH 3rd, Ma Q, Dastrala S, Bennett M, Mitsnefes $M$, Devarajan $P$. (2007): NGAL is an early predictive biomarker of contrastinduced nephropathy in children. Pediatr. Nephrol.. 22(12): 208995.

22. Heinegard D, Tiderstrom G (1973): Determination of serum creatinine by a direct colorimetric method. Clin. Chim. Acta 43(3): 305- 10 .

23. Cruz DN, de Cal M, Garzotto F, Perazella MA, Lentini $P$, Corradi V, Piccinni P, Ronco C (2010): Plasma neutrophil gelatinase-associated lipocalin is an early biomarker for acute kidney injury in an adult ICU population. Intensive Care Med., 36(3):444-51.

24. Kashani K, Al-Khafaji A, Ardiles T, Artigas A, Bagshaw SM, Bell M, Bihorac A, Birkhahn R, Cely CM, Chawla LS, Davison DL, Feldkamp T, Forni LG, Gong MN, Gunnerson KJ, Haase M, Hackett J, Honore PM, Hoste EA, Joannes-Boyau O, Joannidis M, Kim P, Koyner JL, Laskowitz DT, Lissauer ME, Marx G, McCullough PA, Mullaney S, Ostermann M, Rimmelé T, Shapiro NI, Shaw AD, Shi J, Sprague AM, Vincent JL, Vinsonneau C, Wagner L, Walker MG, Wilkerson RG, Zacharowski K, Kellum JA. (2013): Discovery 
and validation of cell cycle arrest biomarkers in human acute kidney injury. Crit Care 17(1):R25.

25. Talving $P$, Karamanos $E$, Skiada D, Lam L, Teixeira PG, Inaba $\mathbf{K}, \quad J o h n s o n \quad J$, Demetriades D (2013): Relationship of creatine kinase elevation and acute kidney injury in pediatric trauma patients. J. Trauma Acute Care Surg., 74(3):912-6.

26. de Geus HR, Betjes MG, Bakker J (2012): Biomarkers for the prediction of acute kidney injury: a narrative review on current status and future challenges. Clin. Kidney J., 5(2):102-108.

27. Cai $X$, Long $Z$, Lin L, Feng $Y$, Zhou N, Mai Q (2012): Serum cystatin $\mathrm{C}$ is an early biomarker for assessment of renal function in burn patients. Clin. Chem. Lab. Med., 50(4):667-71.

28. Aydoğdu M, Gürsel G, Sancak B, Yeni S, Sarı G, Taşyürek S, Türk M, Yüksel S, Senez M, Ozis TN (2013): The use of plasma and urine neutrophil gelatinase associated lipocalin (NGAL) and Cystatin-C in early diagnosis of septic acute kidney injury in critically ill patients. Dis Markers 34(4):237-46. Epub ahead of print.

29. Mårtensson $J$, Bell $M$, Oldner A, Xu S, Venge P, Martling CR (2010): Neutrophil gelatinaseassociated lipocalin in adult septic patients with and without acute kidney injury. Intensive Care Med., 36(8):1333-40.
30. Bagshaw SM, Bennett M, Haase M, Haase-Fielitz A, Egi M, Morimatsu H, D'amico G, Goldsmith D, Devarajan P, Bellomo R (2010): Plasma and urine neutrophil gelatinaseassociated lipocalin in septic versus non-septic acute kidney injury in critical illness. Intensive Care Med., 36(3):452-61.

31. Constantin JM, Futier E, Perbet S, Roszyk L, Lautrette A, Gillart T, Guerin R, Jabaudon $M$, Souweine $B$, Bazin JE, Sapin V (2010): Plasma neutrophil gelatinaseassociated lipocalin is an early marker of acute kidney injury in adult critically ill patients: a prospective study. J. Crit. Care 25(1):176.e1-6.

32. Koyner JL, Garg AX, Coca SG, Sint K, Thiessen-Philbrook $\mathrm{H}$, Patel UD, Shlipak MG, Parikh CR; TRIBE-AKI Consortium (2012): Biomarkers predict progression of acute kidney injury after cardiac surgery. $\mathrm{J}$. Am. Soc. Nephrol., 23(5):905-14.

33. Mellor AJ, Woods D (2012): Serum neutrophil gelatinaseassociated lipocalin in ballistic injuries: a comparison between blast injuries and gunshot wounds. J. Crit. Care 27(4):419.e1-5.

34. Di Somma S, Magrini L, De Berardinis B, Marino R, Ferri E, Moscatelli P, Ballarino P, Carpenteri G, Noto P, Gliozzo B, Palladino L, Di Stasio $\mathbf{E}$ (2013): Additive value of blood neutrophil gelatinase-associated lipocalin to clinical judgment in acute kidney injury diagnosis and 
mortality prediction in patients hospitalized from the emergency department. Crit. Care 17(1):R29.

35. Kümpers $P$, Hafer C, Lukasz A, Lichtinghagen $\mathbf{R}$, Brand $\mathbf{K}$, Fliser D, Faulhaber-Walter R, Kielstein JT (2010): Serum neutrophil gelatinase-associated lipocalin at inception of renal replacement therapy predicts survival in critically ill patients with acute kidney injury. Crit. Care 14(1):R9.

36. Polat M, Fidan K, Derinöz O, Gönen S, Söylemezoglu O (2013): Neutrophil GelatinaseAssociated Lipocalin as a FollowUp Marker in Critically Ill Pediatric Patients with Established Acute Kidney Injury. Ren Fail., 35(3):352-6. Epub ahead of print.

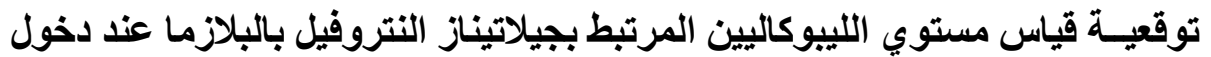

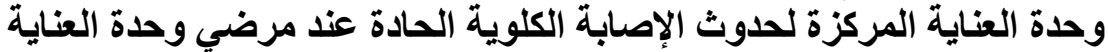 المركزة الجراحية الإلية

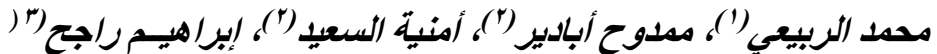

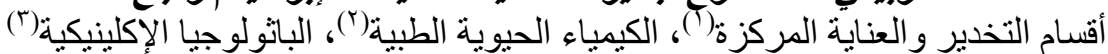 كلبة الطب ـ جامعة بنهاء الكية الطباء}

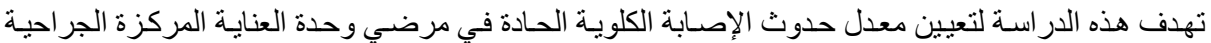

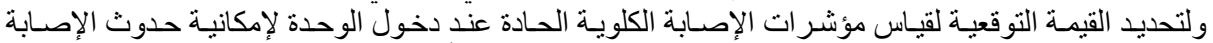

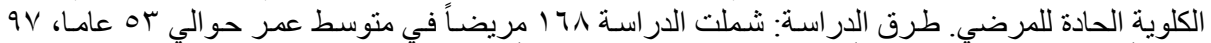

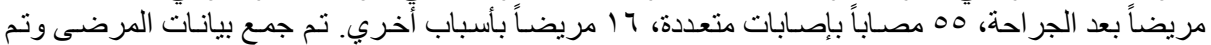

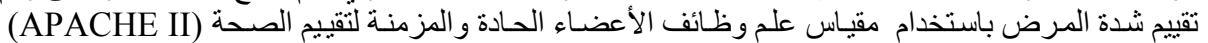

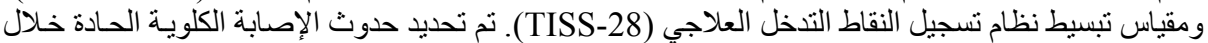

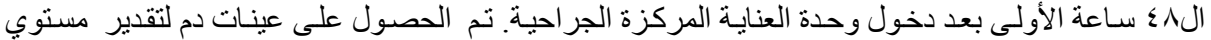

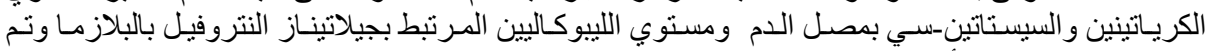

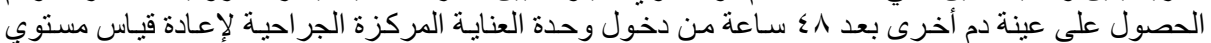
الكرياتينين.

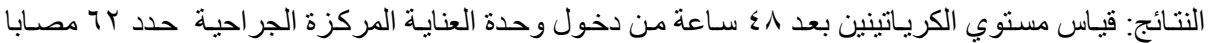

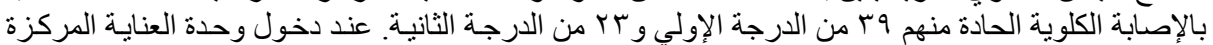

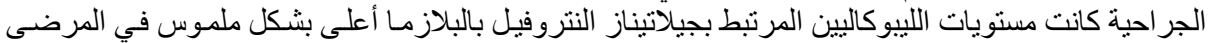

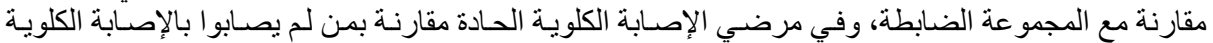

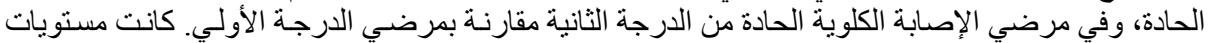

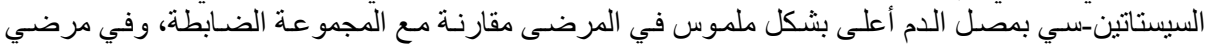

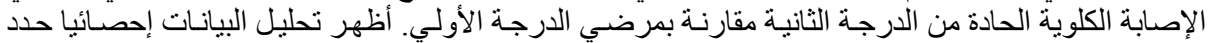

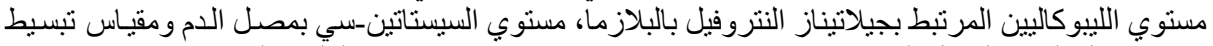

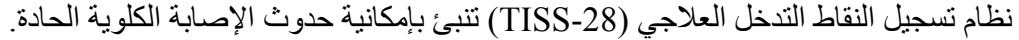

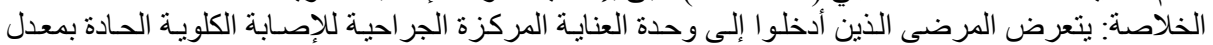

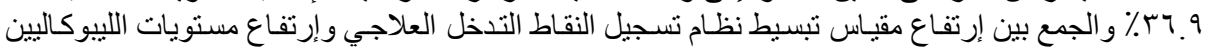

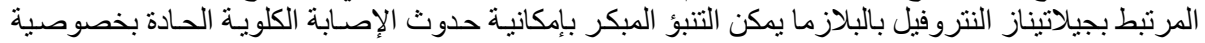
عالية إلى حد كبير. 